\title{
THE STORAGE OF WATER IN, AND HYDRAULIC CHARACTERISTICS OF, THE FIRN OF SOUTH CASCADE GLACIER, WASHINGTON STATE, U.S.A.
}

\author{
by
}

Andrew G. Fountain*

(Project Office-Glaciology, U.S. Geological Survey, Tacoma, WA 98402, U.S.A.)

\begin{abstract}
The porosity and water saturation of the firn of South Cascade Glacier were measured in order to determine both the volume of water stored in it and the significance of this water content for the water volume stored in the glacier. The distance to water below the firn surface was found never to be greater than $4 \mathrm{~m}$, and the average thickness of the water-saturated layer was estimated to be $1.25 \mathrm{~m}$. The average firn porosity was 0.15 , the water saturation was 0.61 , and the total volume of water stored in the firn was approximately $1.78 \times 10^{5} \mathrm{~m}^{3}$ representing about $12 \%$ of the total spring storage. The water table was found to exhibit a pattern of diurnal fluctuation which starts in late June or early July, indicating that melt water from the accumulation zone may pressurize the bed at diurnal frequencies. The depth-averaged permeability was found to be $1.5 \times 10^{-5} \mathrm{~m} / \mathrm{s}$, a value which compares favorably with those from other studies.
\end{abstract}

\section{INTRODUCTION}

The flow of water through a glacier is a complicated process in which many components are poorly understood. One aspect of this process is the flow of water through the firn layer located in the accumulation zone. In temperate glaciers, the firn functions as a thin, unconfined aquifer that stores water and retards its movement to the base of the glacier. This effect is important in determining the magnitude of glacially stored water during a summer season (Tangborn and others, 1975; Östling and Hooke, 1986) and in quantifying the water flux from the glacier surface to its interior. Knowing the water flux is particularly important for time-dependent models of the glacial hydraulic system.

The intention of the present study is to determine the volume of water seasonally stored in the firn layer of a temperate glacier, to estimate its significance for the volume of water stored in the glacier as a whole, and to quantify firn permeability. This report describes the results and implications of several field experiments at South Cascade Glacier, Washington State, U.S.A.

\section{EARLIER WORK}

The presence of a water table at a depth of between 5 and $40 \mathrm{~m}$ in the accumulation zone of temperate glaciers is a common phenomenon (Sharp, 1951; Schommer, 1977; Ambach and others, 1978; Oerter and Moser, 1982). In general, the distance to water from the glacier surface increases with increasing distance up-glacier from its equilibrium line (Ambach and others, 1978). Further, as one would expect from ground-water hydraulics, the slope of the water table roughly approximates to the large-scale

*Present address: U.S. Geological Survey, P.O. Box 25046, MS-412, Denver Federal Center, Lakewood, CO 80225 , U.S.A. surface slope of the glacier, although the two slopes are not parallel (Lang and others, 1976; Schommer, 1977, 1978). The distance to, and thickness of, the water table also varies with its proximity to hydrologic sinks such as crevasses, a fact which is indicated by the lack of water in bore holes near crevasses (Lang and others, 1976; Schommer, 1977).

In general, the water table rises in the spring and falls in the autumn, with little or no variation in the winter (Lang and others, 1976; Schommer, 1977). Such characteristic seasonal fluctuations have been explained by Schommer (1978) and Ambach and others (1981), using numerical and analytical models respectively, as an expected consequence of a porous medium subjected to seasonal input variations. Sudden and otherwise unexpected drops in water levels are commonly associated with the opening of nearby crevasses (Schommer, 1977). Diurnal variations in the water table have been observed in some bore holes (Ambach and others, 1981) but not in others (Lang and others, 1977; Schommer, 1977) despite the fact that the water table was at approximately the same distance below the glacier surface in all cases.

To make a quantitative estimate of water storage and of flow velocity in the firn, a knowledge of its porosity and permeability is required in addition to the thickness of the water layer. The porosity, the ratio of void volume to sample volume, was used by Schommer (1978) as an adjustable parameter in numerical calculations with a magnitude of $0.20-0.30$. Similarly, Ambach and others (1981) used a porosity that varied linearly with depth, with values ranging from 0.50 at the firn surface to 0.10 at the firn-ice transition, independent of actual depth below surface of the water layer. Oerter and Moser (1982) estimated a porosity value of 0.15 , with a water saturation of 0.5 .

Permeability is usually estimated using a standard ground-water aquifer test. The change in water level as a function both of time and of distance from the pumped hole is related to the hydraulic permeability of the medium (Freeze and Cherry, 1979). Results of tests completed by the present and previous investigators are shown in Table I.

Although previous studies measured the depth to the water table and estimated firn permeability, there are no reports of porosity measurements or thickness of the water layer. Therefore, the volume of water stored in the firn cannot be calculated. In addition, permeability has been measured at only one location on each glacier, although it is known that its value can range over one or two orders of magnitude for earthen aquifers (Freeze and Cherry, 1979). For this reason a routine for spatial measurement of permeability values would be desirable.

\section{STUDY SITE}

South Cascade Glacier (Fig. 1) is a small valley glacier located in the Cascade Mountains in the north-western corner of the U.S.A. It ranges in elevation from 1630 to $2100 \mathrm{~m}$ a.s.l., and its equilibrium-line elevation is at approximately $1870 \mathrm{~m}$ a.s.l. The area of the glacier is about 
TABLE I. PERMEABILITY VALUES MEASURED AT SOUTH CASCADE GLACIER IN COMPARISON WITH VALUES MEASURED FOR OTHER GLACIERS. THE ERROR ASSOCIATED WITH THE SOUTH CASCADE VALUES IS APPROXIMATELY $\pm 15 \%$

Location Date Permeability Remarks 1983

$$
\left(\times 10^{-5} \mathrm{~m} / \mathrm{s}\right)
$$

South Cascade 28 Aug. $\quad 12.0$

$\begin{array}{lll}29 & \text { Aug. } & 1.8 \\ 29 & \text { Aug. } & 1.1 \\ 29 & \text { Aug. } & 1.6 \\ 11 & \text { Sep. } & 0.74 \\ 11 & \text { Oct. } & 1.3\end{array}$

Average of the middle values: $1.5 \pm 0.54$ s.d.

\section{Aletschgletcher}

(Schommer, 1978)

$$
1.2 \pm 0.25
$$

Kesselwandferner

(Behrens and others, 1979)

Vernagtferner

(Oerter and Moser, 1982)

$5.0 \pm 1.1$
$2.52 \mathrm{~km}^{2}$, of which $62 \%$ is the accumulation zone. Although the local climate is warm, with a mean annual temperature of about $1{ }^{\circ} \mathrm{C}$ (Meier and others, 1971), the glacier can receive as much as $10 \mathrm{~m}$ of snow during the accumulaiton season, so that the whole accumulation zone is considered to be in the wet snow zone (Paterson, 1981). There have been many previous hydrologically oriented projects (Fountain and Fulk, 1984) with which current findings may be compared.

\section{WATER LEVELS}

Water levels in the firn were measured by digging a snow pit to the firn surface and then drilling a hole into the firn so that a standard water-stage recorder could be placed over this hole. The problems of keeping instruments level on an ablating snow surface were largely avoided by putting a cover over the instruments and refilling the snow pit. Water levels were recorded at the sites shown in Figure 1 for the period 1971-73 (R.M. Krimmel, U.S.G.S., unpublished data) and again for the period 1981-84.

The data (Table II) show that the water table was found no lower than $4 \mathrm{~m}$ below the firn surface, except in cases where observations were made next to crevasses. The distance from firn surface to the water table increased with distance up-glacier, in agreement with the data of Ambach and others (1978), and this variation is related both to the age and to the thickness of the annual layers in the firn.

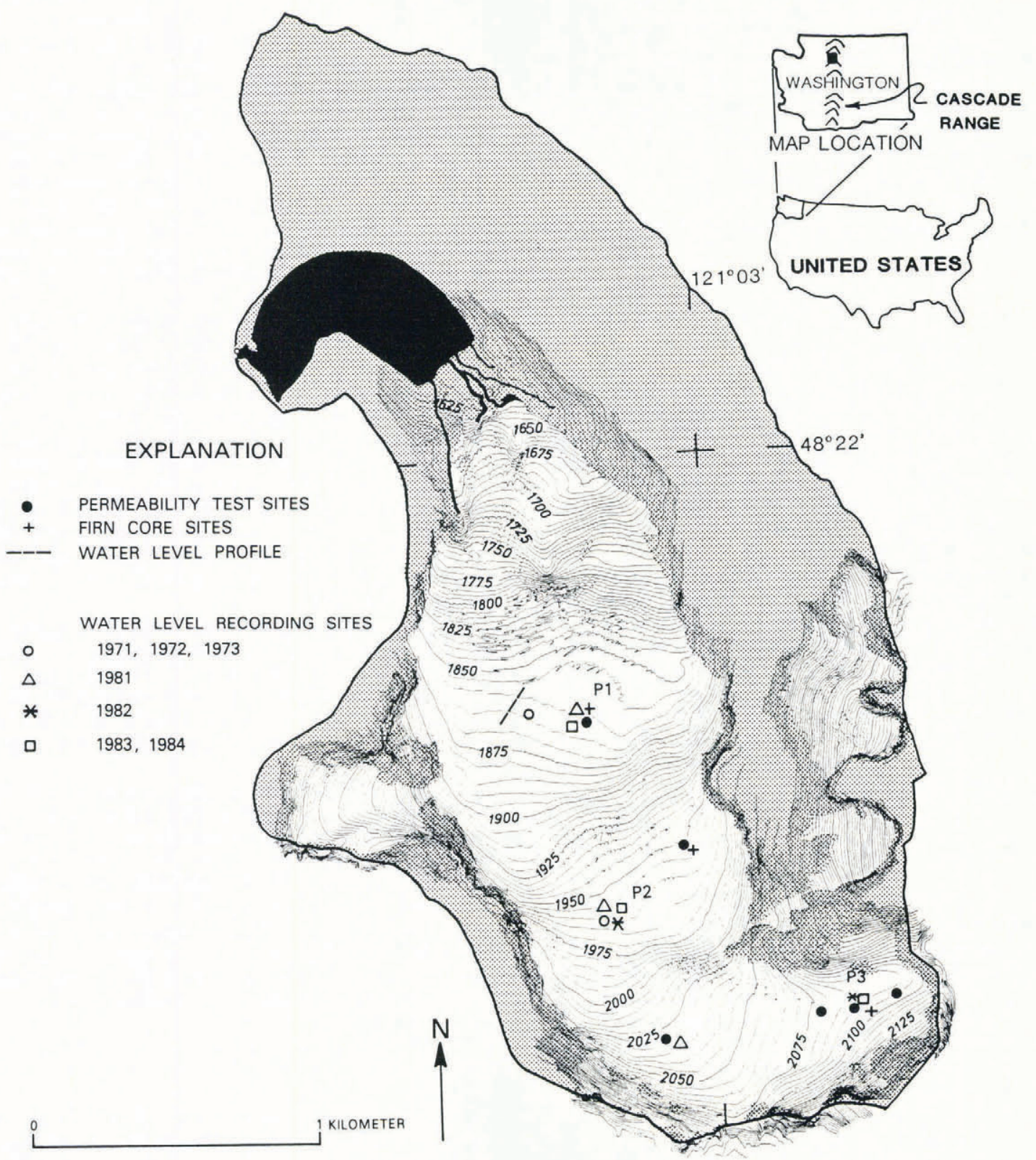

Fig. 1. South Cascade Glacier topographic map, 24 September 1985. The contour interval is $5 \mathrm{~m}$. The equilibrium line is at approximately $1870 \mathrm{~m}$ a.s.l. Locations of the firn water-level recorders, permeability test sites, and core-sample sites are shown. 
TABLE II. SUMMER AVERAGE OF THE DEPTH TO WATER FROM FIRN SURFACE, AND SEASONAL RANGE OF WATER LEVELS. THE LAST TWO MEASUREMENTS WERE MADE IN A CLOSED BASIN WITH NO APPARENT CREVASSES

\begin{tabular}{|c|c|c|c|c|}
\hline $\begin{array}{l}\text { Altitude } \\
\text { (m a.s.1.) }\end{array}$ & $\begin{array}{c}\text { Measurement } \\
\text { year }\end{array}$ & $\begin{array}{l}\text { Depth } \\
\text { to water } \\
\text { (m) }\end{array}$ & $\begin{array}{c}\text { Seasonal rer } \\
\text { range } \\
\text { (m) }\end{array}$ & marks \\
\hline 1850 & 1981 & 0.050 & 0.25 & \\
\hline 1865 & 1971 & 0.300 & 1.25 & \\
\hline 1865 & 1972 & 1.000 & 2.00 & \\
\hline 1865 & 1973 & 2.500 & 2.00 & \\
\hline 1950 & 1983 & 1.500 & 0.50 & \\
\hline 1960 & 1981 & 2.500 & 0.90 & \\
\hline 1960 & 1982 & 3.550 & 1.00 & \\
\hline 2030 & 1981 & 4.000 & 0.20 & $\begin{array}{l}\text { near } \\
\text { crevasse }\end{array}$ \\
\hline 2090 & 1982 & 0 & 0.70 & $\begin{array}{l}\text { closed } \\
\text { basin }\end{array}$ \\
\hline 2090 & 1984 & 1.100 & 0.50 & $\begin{array}{c}\text { closed } \\
\text { basin }\end{array}$ \\
\hline
\end{tabular}
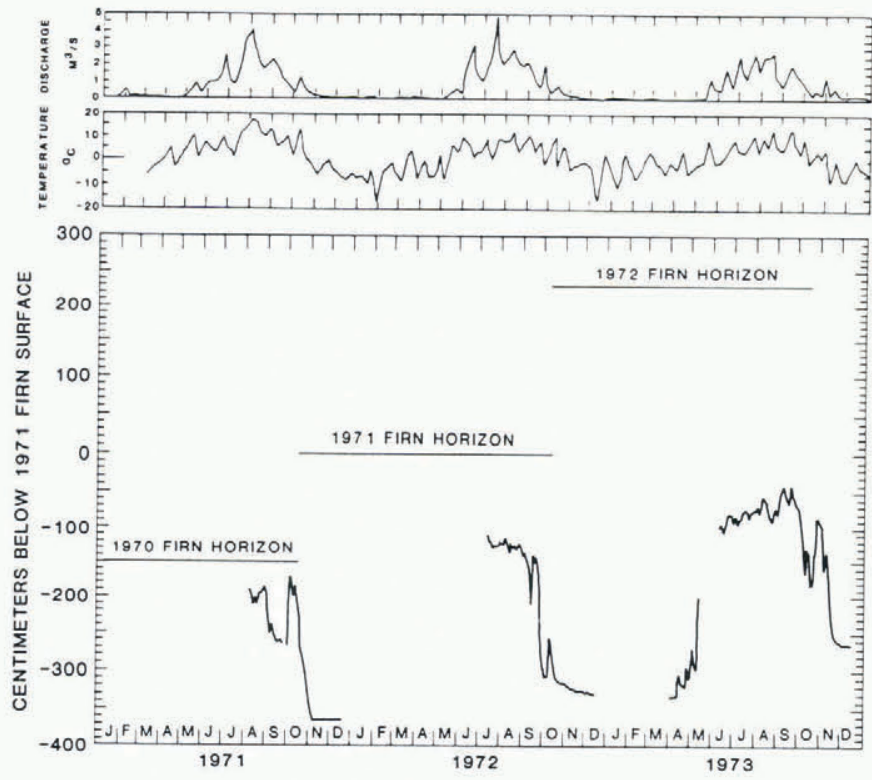

Fig. 2. Firn water levels measured daily for three consecutive summer seasons at the same location ( $R$. Krimmel, U.S.G.S., unpublished data). Note the rise in the minimum water level from season to season. Stream discharge was measured at the outlet of South Cascade Lake and mean daily air temperature was measured at the gauging station.

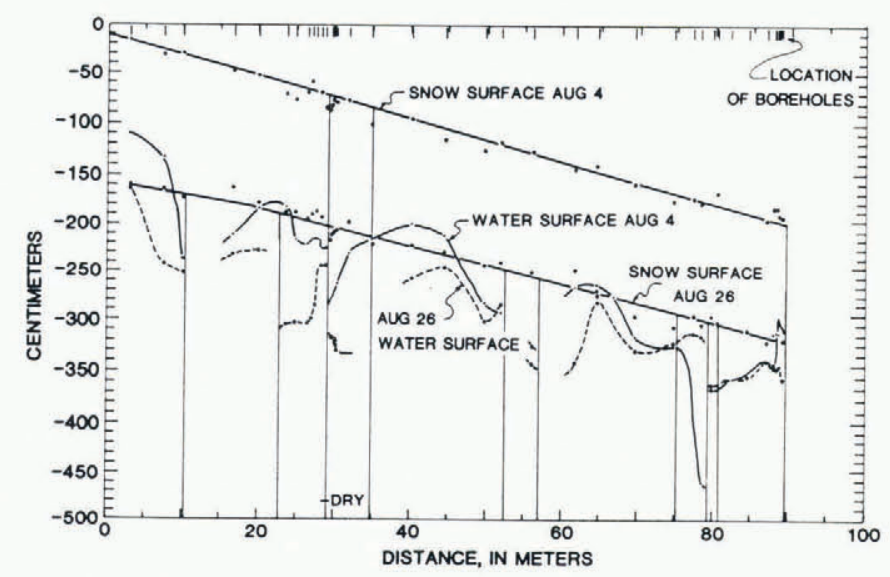

Fig. 3. Snow-surface and water-surface profiles measured in 1980. Location of the profile is shown on Figure 1. The origin is the snow surface at the up-glacier end of the profile on 4 August. Vertical lines represent crevasses known to exist on the date of the surface intersection.
Ideally, annual firn layers are thinner near the equilibrium line and become thicker towards the head of the glacier, corresponding to the gradient of net accumulation. If the firn-ice transition, which is also the bottom of the firn water table, occurs in firn of roughly similar age, the transition at the equilibrium line will be found at the surface and the transition depth will become progressively greater toward the head of the glacier. Local topography causes deviations from the general trend. At South Cascade, a small closed basin relatively free from crevasses exists at the head of the glacier surrounded on three sides by ice-free rock. Run-off from these slopes collects in the basin causing the water table to be located near the surface.

Seasonal water-level variations exhibit some common features despite differences in location and year of measurement. The typical water-level rises for late April or early May are shown by measurements from 1973 (Fig. 2) and by measurements from 1981-84. These rises are associated with an increase in mean daily air temperature to above $0^{\circ} \mathrm{C}$ and represent the start of the active water table. The water level rises quickly to a plateau in late June or early July, indicating that melt-water input approximately equals firn drainage. Peak water levels are observed late in the season, usually in September or early October, which is much later than the peak melt-water input to the glacier indicated by the maxima for run-off and temperature noted in late July or early August (Fig. 2). The firn water usually drains away in late October or November when the input from surface melt and rain has effectively ceased. The late water-level maximum can be explained by changes in firn permeability and is discussed in the next section.

The total seasonal variation in water-level changes depends both on year and on location. In general, it ranges from 0.25 to $2.00 \mathrm{~m}$ (Table II) and the minimum variation occurs near the equilibrium line, where impermeable ice is close to the surface, or near crevasses. The mechanism for draining water from the firn is not clear. It is thought unlikely that a significant volume of water flows through the capillaries along three-grain boundaries (Nye and Frank, 1973) because of the probability of air bubbles cutting off the flow (Raymond and Harrison, 1975). The most probable mechanism is that of water draining into crevasses (Schommer, 1977) along a seepage face where the water table intersects the crevasse. This suggestion is substantiated by observations of dripping crevasse walls and the occasional sound of running water within the crevasses.

To test the hypothesis that crevasses drain the firn, line of holes, each about $4 \mathrm{~cm}$ in diameter, was drilled across two crevasses and the surface elevations and water levels were measured on two occasions. The results are shown in Figure 3. On 4 August 1980, only two crevasses were observed at the snow surface, yet the water level varied significantly and somewhat mysteriously with distance Twenty-two days later the elevation of the surface, which was then firn, and water levels in the holes were re-measured. The water-level variations were similar and can now be explained by the presence of small crevasses which were not visible at the surface on 4 August. The water-surface profile generally showed a maximum midway between crevasses, and was higher on the up-slope side of a crevasse than the down-slope side. The water level was low near the crevasse, indicating that it drains the water. One important implication of these findings is that many small crevasses not visible at the surface, rather than the relatively few obvious gaping crevasses, may be responsible for draining much of the firn. It is also interesting to note that the water surface was continuous across some of the crevasses studied, indicating that not all crevasses drain water from the firn.

The water-level records showed occasional large and rapid changes. Most rises were caused by rainfall, although a direct correspondence is obscured by the infiltration time through the snow-pack which varies with snow-pack thickness and water content (Colbeck, 1972). In addition, thick ice layers within the snow-pack may temporarily pond the melt water (Colbeck, 1973). Sudden drops in water level are caused by a layer of new snow and/or a period of cool, cloudy weather, both of which minimize snow melting and temporarily reduce input. Newly opened crevasses, if close to the recording site, may also cause precipitous drops in water level. 


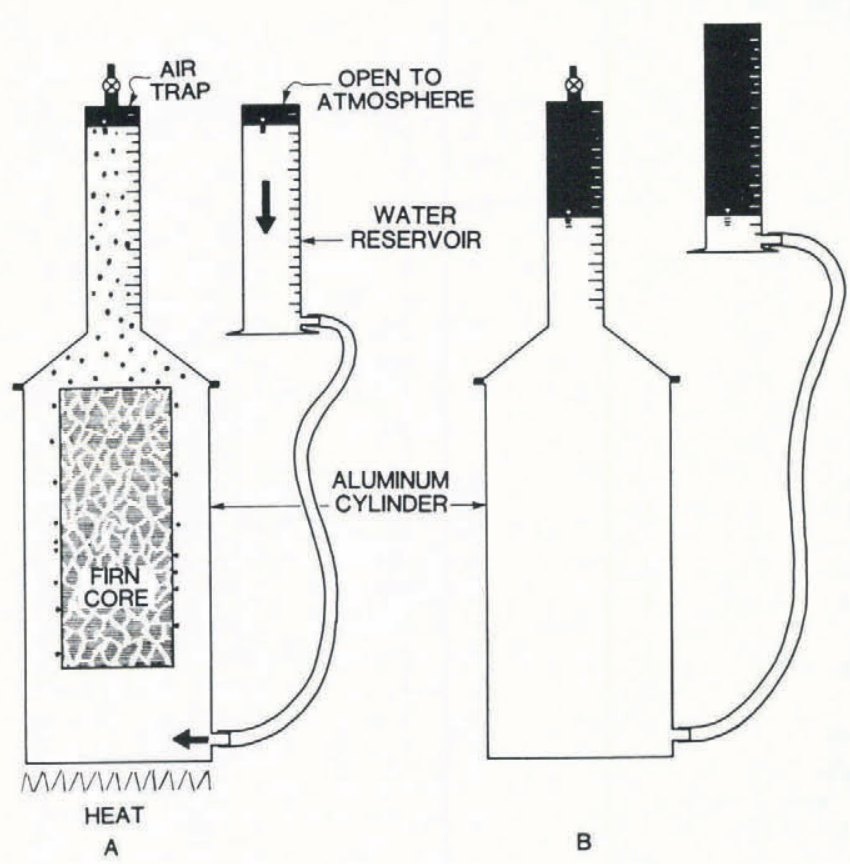

Fig. 4. Diagram showing the apparatus used to measure porosity, water saturation, and ice volume of the firn cores.

Diurnal variations were observed in bore holes, starting in late June or early July when the snow-pack was about $5 \mathrm{~m}$ thick. The fluctuations ranged from 5 to $60 \mathrm{~mm}$ for different bore holes, with a mean of about $25 \mathrm{~mm}$. They lagged behind the peak surface melt rate, which occurred at about $15.00 \mathrm{~h}$ PDT, by $12-15 \mathrm{~h}$ in late June and by about $9-10 \mathrm{~h}$ in late July. Considering that diurnal waves of melt water in a homogeneous snow-pack can penetrate snow depths common to South Cascade Glacier probably is a result of the disintegration of ice layers in the snow-pack that otherwise retard the flow.

For the purposes of this study, the bottom of the water-saturated layer is assumed to be at the point where the medium becomes effectively impermeable, and this is considered to be the same as the winter-minimum water level. Technically, this is not the firn-to-ice transition, because water-filled voids are still present, although the bulk density of material at this position is commonly near or greater than $900 \mathrm{~kg} / \mathrm{m}^{3}$. An estimate of the average thickness of the water layer can be derived from the difference between average-summer water level and winter-minimum water level, assuming that all the water drains from the firn.

\section{POROSITY AND WATER SATURATION}

Porosity was determined by melting sections of firn core. After measuring its volume and mass, each section was inserted into the apparatus shown in Figure 4. The cylinder was capped with a clear plastic air trap and then heated. The air in the core was captured by the air trap. The ice volume in the core was calculated from the decrease in volume of the water reservoir. The change in water volume was caused by density difference during the phase change from ice to water. The volume of liquid water in the core could then be calculated, using continuity after correcting all the volumes for temperature-induced density changes, from

$$
V_{\text {water }}=V_{\text {total }}-V_{\text {air }}-V_{\text {ice }}
$$

where $V_{\text {water }}$ is the water volume, $V_{\text {total }}$ is the total volume of the core, $V_{\text {ir }}$ is air volume, and $V_{\text {ice }}$ is ice volume. From Equation (1) the porosity, $\phi$, and water saturation, $S_{\mathrm{w}}$, can be calculated, since

$$
\phi=\frac{V_{\text {air }}+V_{\text {water }}}{V_{\text {total }}}
$$

where porosity is the ratio of void volume to total volume, and

$$
S_{\mathrm{w}}=\frac{V_{\text {water }}}{V_{\text {air }}+V_{\text {water }}}
$$

where the water saturation is the ratio of water volume to void volume.

Porosity, water saturation, and density measurements were made on firn cores taken from three locations on the glacier in 1983 (Fig. 1). The average core length was approximately $8.5 \mathrm{~m}$, and each core section for which the measurements were made was an average of $0.15 \mathrm{~m}$ long. It was expected that the porosity should decrease continuously with depth to the firn-ice transition, at which point the porosity change would be discontinuous and have a much smaller value. Also, because older firn has been exposed to more seasons of melt-water drainage and to high water saturation levels, it was expected that it would show lower porosities than younger firn because of compaction. Because most of the core would be taken from below the level of the water table, the water saturation was expected to remain approximately constant. The results obtained are shown in Figure 5 and are smoothed by a running mean of three measurements. Surprisingly, neither a systematic decrease in porosity nor an obvious firn-ice transition appears, and the porosity values are relatively uniform between cores despite their origins in different locations in the accumulation zone. The mean porosity values were $0.17,0.13$, and 0.15 , and these differences between cores are considered insignificant relative to the variability within each core. The averaged porosity of 0.15 is in agreement with the estimate made by Oerter and Moser (1982).

One possible explanation for the lack of a firn-ice transition causing a change in porosity values is that the cores did not fully penetrate the firn into the ice. Could this be the case? At no location has the water level ever been observed to drop to more than $4 \mathrm{~m}$ below the top of the firn, and the maximum annual variation observed on this glacier is only $2 \mathrm{~m}$. On the basis of these figures, the maximum depth of the firn bottom is no more than $6 \mathrm{~m}$ below the firn surface. Furthermore, in 1983, when the porosity measurements were made, the maximum depth of the water surface was not observed to be greater than $2 \mathrm{~m}$ below the firn surface. Thus the cores must have penetrated the aquifer and extended well into the impermeable ice below.

The observation that porosity does not vary uniformly with depth, fails to change at the firn-ice transition, and is relatively constant everywhere in the accumulation zone, including near the equilibrium line, can be explained in terms of the microstructure of the firn. The firn-porosity value of 0.15 is much smaller than either the laboratory porosity measurements of packed spheres, 0.40 , or their theoretical mimimum, 0.26 (Paterson, 1981). Therefore, a packed-sphere model for the firn is considered inappropriate. The void space is likely to resemble a braided network of beads on strings, where the beads are the larger voids and the strings represent the smaller connecting passageways (fig. 8 in Colbeck, 1982). In this model, permeability is reduced as some of the passageways freeze up, whereas porosity is hardly affected. This hypothesis is qualitatively substantiated by experiments attempting to suck water out of the firn core. Despite appearances, identical looking cores are found to have greatly varying permeability so that no consistent prediction of permeability based on appearance could be made except in the case of clear ice.

Averaged water saturation was also found to be similar in each core, $0.69,0.51$, and 0.62 . As with the porosity data, the differences in mean saturation between cores were smaller than the variations within each individual core; the averaged water-saturation value was 0.61 and the variation in each core was large. There seems to be a weak trend towards greater saturation at greater depth. This is thought reasonable because air will tend to migrate upwards. At water-saturation values greater than 0.14 , trapped air occurs as individual bubbles between the ice grains and water forms a continuous path completely surrounding each grain (Scheidegger, 1957). 
P3 CORE
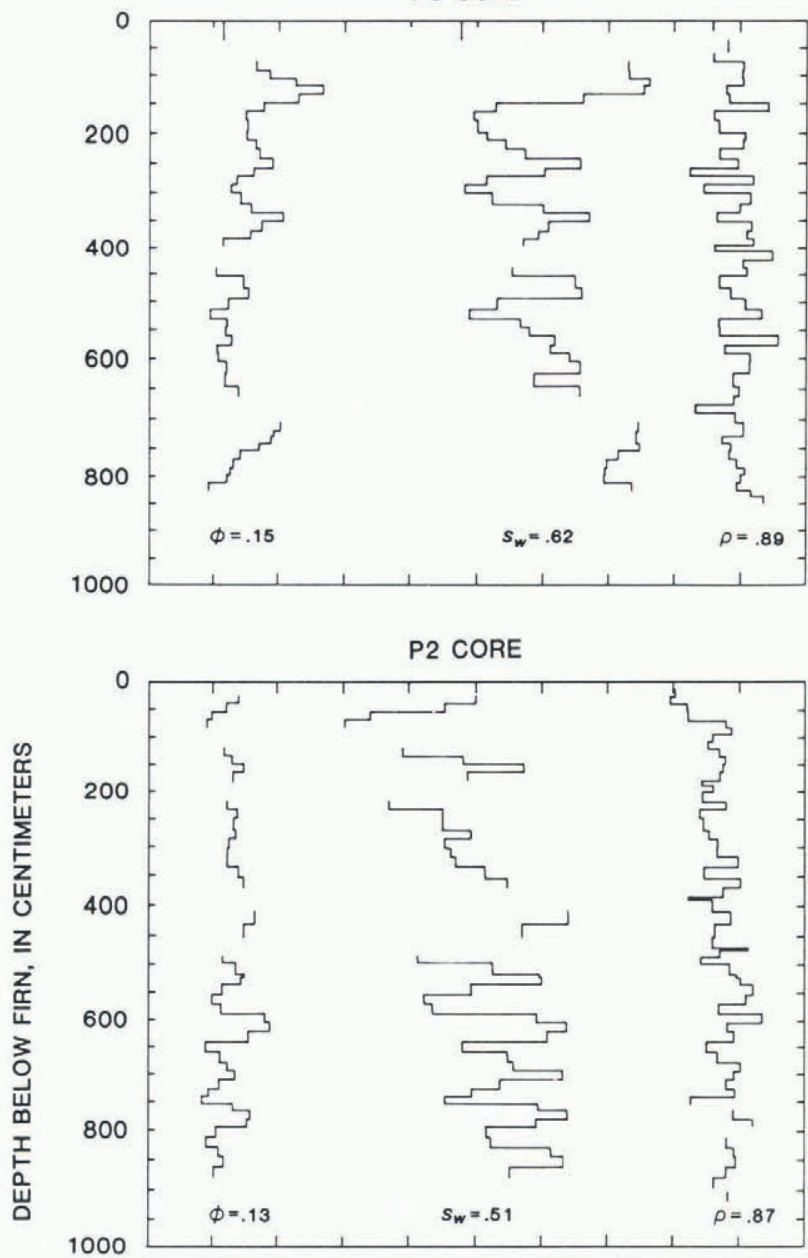

B.

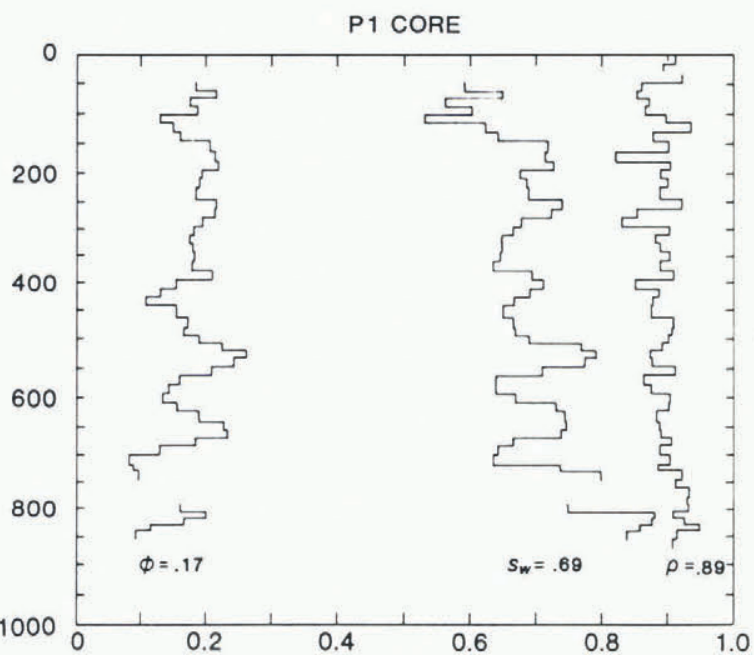

Fig. 5. Porosity $(\phi)$, water saturation $\left(S_{\mathrm{w}}\right)$, and density $(\rho)$ profiles at each core site. The data have been smoothed by a running mean of three measurements. Averaged values for each profile are indicated at the bottom of the figure.

An error analysis shows potentially large errors in the final results for porosity and water saturation, in agreement with the analysis of Colbeck (1978). However, the actual errors in the porosity and water saturation are much smaller, averaging 0.02 and 0.04 (that is, $\pm 2 \%$ and $4 \%$ ), respectively. These values are based on the measured mass of each core section compared with its mass calculated from the experimentally determined values of water and ice volumes. The differences are assumed to result from errors in the volume calculation rather than errors in the measurement of mass, and therefore the error has been partitioned between the water volume and the ice volume according to the expected relative error derived from the error analysis.

\section{PERMEABILITY}

Permeability was measured on site using a common ground-water technique - the slug test (Cooper and others, 1967). In this procedure a volume of water is instantaneously displaced in a bore hole above or below the equilibrium level, and the rate at which the water level regains equilibrium is related to the permeability of the medium. Although this technique is not as accurate as the pump test (Freeze and Cherry, 1979), it does have two advantages over it. First, only one hole is required for a test and this reduces preparation time and instrument needs Secondly, the radius of influence around the hole is much smaller than that for the pump test and so the possiblity of the location of crevasses affecting measurements is reduced.

In the application of the slug test to South Cascade Glacier, a weighted cylinder about $0.4 \mathrm{~m}$ long and $0.1 \mathrm{~m}$ wide was lowered into the water. Once equilibrium was reached, that is after about $30 \mathrm{~min}$, it was rapidly removed and subsequent changes in water level were continuously monitored with a pressure transducer. Following the procedure outlined by Bouwer and Rice (1976), the permeability was calculated from the time-rate change of the recovery water level. The largest uncertainty in the permeability calculations is the estimation of the thickness of the saturated aquifer. This was estimated, from the seasonal water-level change, as explained previously.

Permeability was measured at seven different locations of which six yielded reliable results, during the summer of 1983 (Fig. 1). Table I summarizes the results and includes measured values from other studies for comparison. The permeability values measured at South Cascade Glacer are close to previously reported values for other glaciers. The first permeability value in Table $I$ is very large, because at this hole the water level penetrated $0.11 \mathrm{~m}$ into the seasonal snow-pack, which has a larger permeability. The smallest permeability was observed at the equilibrium line, where the surface of the firn was very old, and at the glacier surface. This value appears to be an overestimate, because the presence of nearby ponded surface water indicates a very small permeability. Surface water may percolate through the surface layer to the bore hole, yielding an anomalously higher reading for permeability. The remaining permeability values are considered to be representative of the accumulation zone and are equivalent to the permeability of a silty-to-clean sand (Freeze and Cherry, 1979).

The relatively uniform permeability values for the other four sites is, at first, surprising. However, it may be explained if one considers that the water table quickly modifies its own environment by accelerating snow- or firn-grain growth to some quasi-equilibrium radius (Wakahama, 1968). Therefore, the hydraulic characteristics of the medium are fairly uniform for thickness-averaged values. One would expect a vertical decrease in permeability because the firn is exposed to water-saturated conditions for longer periods closer to the base of the water table than it is at higher levels. Unfortunately, the permeability tests performed on the firn cannot resolve the vertical gradient.

\section{FIRN COMPACTION}

Evidence of firn becoming impermeable is presented in Figure 2. The water level was measured at the same location for 3 years, and it can be seen that the minimum water level relative to the 1971 firn surface rose every year. Assuming that all but the irreducible water saturation drains out of the firn by late November or early December, the minimum water level is also the bottom of the water table and is the firn-ice transition. Figure 2 shows that $0.35 \mathrm{~m}$ of firn became impermeable in 1972 and that approximately $0.70 \mathrm{~m}$ was transformed in 1973. These changes occurred in the summers in conditions of water saturation rather than during the winters, suggesting that compaction is accelerated at higher water saturations (Colbeck and Parssinen, 1978). 
The compaction of porous firn to impermeable firn is the formation of glacier ice. This provides one explanation for the possibility of water tables reaching a maximum level late in the season after the peak in surface melt has passed, such as happened in 1973 (Fig. 2). If we can assume that the input to, and output from, the firn are fairly constant during the summer, then a rise in water level is the result of the bottom layers of porous firn becoming impermeable. Another factor which may reinforce the compaction hypothesis, or dominate that process during the autumn, is the freezing of crevasse walls. Because crevasses act as sinks for water in the firn, wall freezing would reduce their permeability and consequently the water level in the firn would rise.

\section{FIRN WATER STORAGE}

The volume of water stored seasonally in the firn can be calculated from

$$
V_{\mathrm{w}}=A h \phi S_{\mathrm{w}}
$$

where $V_{\mathrm{w}}$ is total volume, $A$ is the area of the firn, that is the accumulation zone, $h$ is the thickness of the water table, $\phi$ is porosity, and $S_{\mathrm{W}}$ is water saturation. The averaged values for porosity and water saturation are 0.15 and 0.61 , respectively, and the area, determined by use of the $1860 \mathrm{~m}$ elevation contour as the equilibrium line, is approximately $1.56 \times 10^{6} \mathrm{~m}^{2}$. The thickness of the watersaturated layer can be estimated from the seasonal range of water levels (Table II) to be about $1.25 \mathrm{~m}$. This value is somewhat arbitrary, given the variability of water surface and hence of the thickness of the saturated layer over short distances and between years (Fig. 3). The total volume of stored water is thus calculated to be about $1.78 \times 10^{5} \mathrm{~m}^{3}$, equivalent to a layer of water $0.11 \mathrm{~m}$ thick over an area the size of the accumulation zone. Relative to the whole glacier area, this water layer would be $0.07 \mathrm{~m}$ thick.

Tangborn and others (1975) have determined the amount of water stored in South Cascade Glacier during the 1970 field season, and they found a maximum storage value of $1.5 \times 10^{6} \mathrm{~m}^{3}$. If the amount of water stored in the firn is approximately constant from summer to summer this figure would have accounted for $12 \%$ of the total water storage in 1970; the remaining water must have been stored within, or at the bed of, the glacier. Storage occurs in spring as snow and unsaturated firn soak up the early melt water prior to significant drainage. The decrease in storage which Tangborn and others (1975) observed after early June must have been caused by the draining of englacial or subglacial sources, because the firn water table remained high for most of the summer season (Fig. 2).

The appearance of diurnal fluctuations in the firn water table indicates that, contrary to the assumption of Humphrey and others (1986), the accumulation zone can influence subglacial hydraulics at a diurnal frequency. Considering the fact that the surface melt water in the accumulation zone is roughly half of that in the ablation zone suggests that sufficient water flux is available. If the travel time for water through the body of a glacier to its bed is the same in both the accumulation and the ablation zone, then the water-pressure variations at the bed in the accumulation zone would be expected to be about $12 \mathrm{~h}$ behind parallel variations at the bed in the ablation zone. Whether diurnal fluctuations are of sufficient magnitude significantly to affect the subglacial water pressure in the accumulation zone is not clear.

\section{CONCLUSIONS}

The firn water table is an important link between the percolation of melt water from the surface and its final drainage into the body of the glacier via crevasses. The firn on South Cascade Glacier has a depth-averaged permeability of approximately $1.5 \times 10^{-5} \mathrm{~m} / \mathrm{s}$ and a relatively low liquid-water content of approximately 0.09 (or 9\%). Because their spatial variations are small, these values are thought to be representative of the firn. The storage of melt water in the firn represents approximately $12 \%$ of the total spring storage of water in the glacier. Diurnal fluctuations are present in the firn water table in late June and are roughly $12 \mathrm{~h}$ out-of-phase with melt-water drainage in the ablation zone. This has interesting implications for the movement of glaciers.

The effect of firn compaction is shown by the year-to-year increase in the minimum firn water level. It is suggested that the decreasing permeability of the bottom of the porous firn is probably responsible for this increase in level. The maintenance of high water levels long after the peak in melt-water production is caused by the firn becoming less porous and/or by freezing of the crevasse walls and consequent restriction of drainage. It is interesting to note that porosity and water-saturation values do not vary significantly with depth in the impermeable firn, indicating that firn-to-ice compaction in temperate glaciers is a slow and complicated process.

\section{ACKNOWLEDGEMENTS}

B. Vaughn greatly aided this study by assistance in the field and subsequently with data reduction. Gratitude is expressed to R. Krimmel for the use of his data, which resulted in Figure 2. The clarity of this paper was significantly improved by the comments of both S. Colbeck and R. Hooke.

\section{REFERENCES}

Ambach, W., and 9 others. 1978. Untersuchungen der Wassertafel am Kesselwandferner (Ötztaler Alpen) an einem 30 Meter tiefen Firnschacht. Z. Gletscherkd. Glazialgeol., 14(1), 61-71.

Ambach, W., M. Blumthaler, and P. Kirchlechner. 1981 Application of the gravity flow theory to the percolation of melt water through firn. J. Glaciol., 27(95), 67-75.

Behrens, H., and 7 others. 1979. Neue Ergebnisse zur Bewegung des Schmelzwassers im Firnkörper des Akkumulationsgebietes eines Alpengletschers (Kesselwandferner/Ötztaler Alpen). Z. Gletscherkd. Glazialgeol., 15(2), 219-228.

Bouwer, H. and R. Rice. 1976. A slug test for determining hydraulic conductivity of unconfined aquifers with completely or partially penetrating wells. Water Resour. Res., 12(3), 423-428.

Colbeck, S.C. 1972. A theory of water percolation in snow. J. Glaciol., 11(63), 369-385.

Colbeck, S.C. 1973. Effects of stratigraphic layers on water flow through snow. CRREL Res. Rep. 311.

Colbeck, S.C. 1978. The difficulties of measuring the water saturation and porosity of snow. J. Glaciol., 20(82), 189-201.

Colbeck, S.C. 1982. An overview of seasonal snow metamorphism. Rev. Geophys. Space Phys., 20(1), 45-61.

Colbeck, S. and G. Davidson. 1973. Water percolation through homogeneous snow. International Association of Hydrological Sciences Publication 107 (Symposium at Banff 1972 - Role of Snow and Ice in Hydrology), 242-257.

Colbeck, S.C. and N. Parssinen. 1978. Regelation and the deformation of wet snow. J. Glaciol., 21(85), 639-650.

Cooper, H., J. Bredehoeft, and I. Papadopulos. 1967. Response of a finite diameter well to an instantaneous charge of water. Water Resour. Res., 3, 263-269.

Fountain, A. and M. Fulk. 1984. South Cascade Glacier bibliography. U.S. Geol. Surv. Open-File Rep. 84-441.

Freeze, A. and J. Cherry. 1979. Groundwater. Englewood Cliffs, NJ, Prentice-Hall.

Humphrey, N., C. Raymond, and W. Harrison. 1986. Discharges of turbid water during mini-surges of Variegated Glacier, Alaska, U.S.A. J. Glaciol., 32(111), 195-207.

Lang, H., B. Schädler, and G. Davidson. 1977. Hydroglaciological investigations on the Ewigschneefeld-Gr. Aletschgletscher. Z. Gletscherkd. Glazialgeol., 12(2), 1976, 109-124.

Meier, M., W. Tangborn, L. Mayo, and A. Post. 1971. Combined ice and water balances of Gulkana and Wolverine Glaciers, Alaska, and South Cascade Glacier, 
Washington, 1965 and 1966 hydrologic years. U.S. Geol. Surv. Prof. Pap. 715-A.

Nye, J.F. and F.C. Frank. 1973. Hydrology of the intergranular veins in a temperate glacier. International Association of Hydrological Sciences Publication 95 (Symposium at Cambridge $1969-$ Hydrology of Glaciers), 157-161.

Oerter, H. and H. Moser. 1982. Water storage and drainage within the firn of a temperate glacier (Vernagtferner, Oetztal Alps, Austria). International Association of Hydrological Sciences Publication 138 (Symposium at Exeter 1982 - Hydrological Aspects of Alpine and High-Mountain Areas), 71-82.

Östling, M. and R. LeB. Hooke. 1986. Water storage in Storglaciären, Kebnekaise, Sweden. Geogr. Ann., 86A(4), 279-290.

Paterson, W. 1981. The physics of glaciers. Second edition. Oxford, etc., Pergamon Press.

Raymond, C.F. and W.D. Harrison. 1975. Some observations on the behavior of the liquid and gas phases in temperate glacier ice. J. Glaciol,, 14(71), 213-233.

Scheidegger, A.E. 1957. The physics of flow through porous media. New York, Macmillan Publishing.

Schommer, P. 1977. Wasserspiegelmessungen im Firn des Ewigschneefeldes (Schweizer Alpen). Z. Gletscherkd. Glazialgeol., 12(2), 1976, 125-141.

Schommer, P. 1978. Rechnerische Nachbildung von Wasserspiegel ganglinien im Firn und Vergleich mit Feldmessungen im Ewigschneefeld (Schweizer Alpen). Z . Gletscherkd. Glazialgeol., 14(2), 173-190.

Sharp, R.P. 1951. Meltwater behavior in firn on upper Seward Glacier, St Elias Mountains, Canada. International Association of Scientific Hydrology Publication 32 (General Assembly of Brussels 1951 - Snow and Ice), 246-253.

Tangborn, W.V., R.M. Krimmel, and M.F. Meier. 1975. A comparison of glacier mass balance by glaciological, hydrological, and mapping methods, South Cascade Glacier, Washington. International Association of Hydrological Sciences Publication 104 (General Assembly of Moscow 1971 - Snow and Ice), 185-196.

Wakahama, G. 1968. The metamorphism of wet snow. International Association of Scientific Hydrology Publication 79 (General Assembly of Bern 1967 - Snow and Ice), 370-379. 